\title{
METAL-5-FLUOROURACIL-HISTAMINE COMPLEXES: SOLUTION, STRUCTURAL, AND ANTITUMOUR STUDIES
}

\author{
Sadhna Tyagi ${ }^{1}$, Sukh Mahendra Singh ${ }^{2}$, Sujan Gencaslan ${ }^{3}$, \\ W.S. Sheldrick ${ }^{3}$ and Udai P. Singh ${ }^{1 *}$ \\ ${ }^{1}$ Department of Chemistry, Indian Institute of Technology Roorkee, Roorkee - 247 667, India \\ ${ }^{2}$ School of Biotechnology, Banaras Hindu University, Varanasi - 221005 , India \\ ${ }^{3}$ Lehrstuhl für Analytische Chemie, Ruhr-Universität Bochum, D-44801 Bochum, Germany
}

\begin{abstract}
Solution studies were performed $\mathrm{pH}$-metrically to study the interaction of $\mathrm{Co}(\mathrm{II}), \mathrm{Ni}(\mathrm{II}), \mathrm{Cu}(\mathrm{II}), \mathrm{Zn}(\mathrm{II})$ and $\mathrm{Cd}$ (II) metal ions with 5-fluorouracil (5FU) and histamine ( $\mathrm{Hm})$ separately (binary) and in the presence of each other (ternary) at $25 \pm 0.1{ }^{\circ} \mathrm{C}$ temperature and a constant ionic strength of $0.1 \mathrm{M} \mathrm{NaNO}$ in aqueous solution. The ternary complexes have been found to be more stable than the corresponding binary complexes as shown by the positive value of $\Delta \log \mathrm{K}$. The species distribution curves have been obtained using the computer programme BEST. On the basis of species distribution results, efforts were also made to prepare some mixed complexes of $\mathrm{Co}(\mathrm{II}), \mathrm{Ni}(\mathrm{II}), \mathrm{Cu}(\mathrm{II}), \mathrm{Zn}(\mathrm{II})$ and $\mathrm{Cd}(\mathrm{II})$ ions by performing the reaction of their metal nitrates, $5 \mathrm{FU}$ and $\mathrm{Hm}$ in aqueous ethanol medium at suitable $\mathrm{pH}$. The isolated solid complexes were characterized by different physico-chemical method in order to suggest the possible binding site of the ligands and the structure of the resultant complexes. All these complexes were checked for their antitumour activity by injecting in Dalton's lymphoma (DL) and Sarcoma-180 (S-180) bearing $\mathrm{C}_{3} \mathrm{H} / \mathrm{He}$ mice. The results indicate that some complexes have good antitumour activity both in vivo and in vitro.
\end{abstract}

\section{INTRODUCTION}

5-Fluorouracil (5FU), a mono fluorinated product of uracil, has entirely different biological properties than uracil [1]. Since the time of its synthesis, 5FU has been increasingly employed alone or in combination with other cytotoxic drugs and hormones in the medical treatment of solid tumours. It has also been used in the treatment of breast, lung, ovary and cervix carcinomas [2]. The antitumour properties of 5FU against different tumour systems has also been found to be significantly enhanced by the co-administration of guanosine (in any combination) resulting in therapeutic synergism [3]. The mechanism of action of 5FU is not well known. In 1986, Joshi et al. [4] suggested that the 5FU is anabolised to 5-fluoro-2'-dexoyuridylic acid, a potent competitive inhibitor of thymidylate synthetase, and the enzyme which normally converts 2 'deoxyuridylic acid to thymidylic acid as essential component of DNA. This is due to the presence of fluorine atom at the critical C-5 position. Since 5FU and its anabolites are concentrated in cancer cells, this enzymatic blockade inhibits tumour growth by causing thymineless death of neoplastic cells. Histamine (Hm), a decarboxylated product of histidine, is a potent vasodilator and is released in certain tissue as a result of allergic hypersensitivity or inflammation. Histamine also plays an important role in diseases.

The antitumour properties of 5FU and scanty information on its metal complexes in combination with histamine as antitumour agent encouraged to undertake solution, solid and antitumour activity studies of 5FU-Histamine mixed complexes.

Although several workers have reported the antitumor properties of 5FU and its metal complexes [5], also the solution studies on 5FU [6] and histamine separately [7], the work on the chemotherapeutic properties of 5FU-histamine metal complexes is not available in the literature.<smiles>O=c1[nH]cc(F)c(=O)[nH]1</smiles>

5-Fluorouracil<smiles>NCCc1c[nH]cn1</smiles>

Histamine

Fig. 1. Structures of 5-fluorouracil and histamine.

The present paper reports the solution, structural and antitumour studies of $\mathrm{Co}(\mathrm{II}), \mathrm{Ni}(\mathrm{II}), \mathrm{Cu}(\mathrm{II}), \mathrm{Zn}$ (II) and $\mathrm{Cd}(\mathrm{II})$ complexes with 5-fluorouracil (5FU) as one ligand, and histamine (Hm) as another ligand. 


\section{RESULT AND DISCUSSION}

\section{Solution studies}

The pH-metric titration curves (Figure 2a-e) were plotted as pH vs. a (where a is the number of moles of alkali required per mole of the ligand) for 5FU (curve a), M-5FU (curve b), Hm (curve c), M-Hm (curve d) and M-5FU-Hm (curve e) systems. The deprotonation constant values $\left(\mathrm{pK}_{\mathrm{n}}\right)$ and various formation ccnstants for binary and ternary systems (Table 1) were calculated by using the literature method [8] and the computer programs pKAS and BEST [9] respectively. From the ligand curves a and c, the first proton dissociation constant $\left(\mathrm{pK}_{1}\right)$ values for $5 \mathrm{FU}$ and $\mathrm{Hm}$ are calculated to be $7.55 \pm 0.06$ and $6.20 \pm 0.06$ by considering the first deprotonation equilibrium $\mathrm{H}_{2} \mathrm{~L}==\mathrm{H}^{+}+\mathrm{HL}^{-}$and computer program pKAS [9]. Similarly, the second deprotonation $\mathrm{HL}^{-}==\mathrm{H}^{+}+\mathrm{L}^{-2}$ constant $\left(\mathrm{pK}_{2}\right)$ values are also evaluated to be $10.60 \pm 0.03$ and $9.85 \pm 0.04$ for the two ligands, respectively.

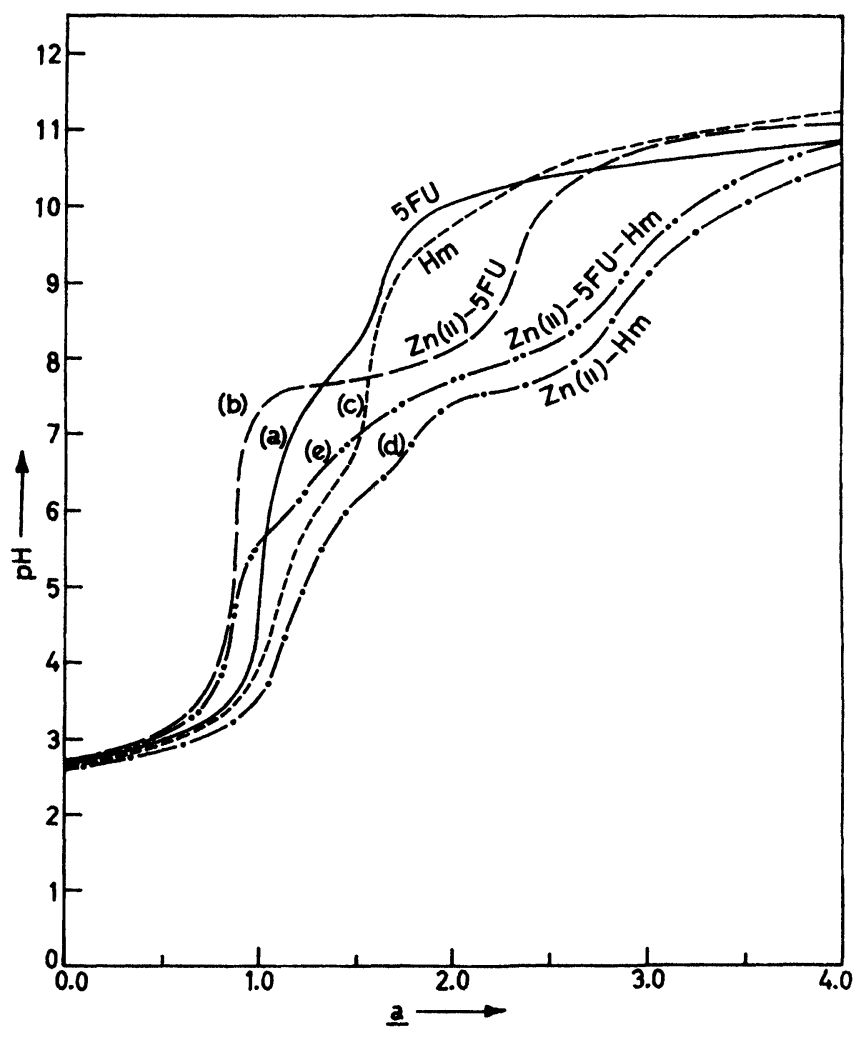

Fig. 2. $\mathrm{pH}$ metric titration curves of (a) 5-fluorouracil solution ( $1.0 \mathrm{mM})$, (b) metal ion $(1.0 \mathrm{mM})+[\mathrm{a}]$, (c) histamine $(1.0 \mathrm{mM})$, (d) metal ion $(1.0 \mathrm{mM})+[\mathrm{c}]$, (e) metal ion $(1.0 \mathrm{mM})+[\mathrm{a}]+[\mathrm{c}]$ at $\mathrm{T}=25 \pm 0.1^{\circ} \mathrm{C}$ and $\mu$ $=0.1 \mathrm{M}\left(\mathrm{NaNO}_{3}\right)$ in aqueous solution. Where a is number of mole of alkali per mole of ligand.

In Fig. 2, the titration curves $b$ and $d$ account for the association of metal ions with $5 \mathrm{FU}$ (curve b) and $\mathrm{Hm}$ (curve d), respectively. The overall stability constant for each binary system, M-5FU as well as M-Hm was evaluated by using the method described earlier [8] and the BEST computer programme [9].

The order of stability of $1: 1$ binary system of $5 \mathrm{FU}$ and $\mathrm{Hm}$ is $\mathrm{Co}(\mathrm{II})<\mathrm{Ni}(\mathrm{II})<\mathrm{Cu}(\mathrm{II})>\mathrm{Zn}(\mathrm{II})>\mathrm{Cd}(\mathrm{II})$, which is in conformity with Irving-William's order. Although the $\mathrm{Cu}(\mathrm{II})$ complexes should have higher stability as compare to the $\mathrm{Co}$ (II) and $\mathrm{Ni}$ (II) complexes but it has been found to be unusually higher than could be expected from the ionic radii and electronegativity considerations. It may be attributed to the unique electronic configuration $\left(\mathrm{d}^{9}\right)$ of the $\mathrm{Cu}(\mathrm{II})$ ion which is capable of additional stabilization due to the JahnTeller distortion [10]. In addition to this, the Hm molecule is supposed to be the more basic than 5FU, hence M(II)-Hm systems should be more stable than the corresponding M(II)-5FU systems, which is also supported from the results presented in Table 1. It may be due to the binding nature of $\mathrm{Hm}$ as it binds with metal ions through both the imidazole and amine groups produce a chelate ring that enhances the stability of metal complexes of $\mathrm{Hm}$. The titration curve clearly exhibits the interaction of $5 \mathrm{FU}$ and $\mathrm{Hm}$ with metal ions in the 
presence of each other. The stability constants of various ternary metal-ligand systems were evaluated by using a previous method [8] and the BEST computer programme [9] (Table 1). The overall stability constants of the binary and the corresponding ternary metal-ligand complexes were compared and it has been found that the ternary complexes are more stable than the metal-5FU complexes but are less stable than the corresponding metal-Hm complexes. It may be due to higher concentration of the electrons around the [M$5 \mathrm{FU}]^{+}$system in comparison to the $\left[\mathrm{M}_{(}\left(\mathrm{H}_{2} \mathrm{O}\right)_{\mathrm{n}}\right]^{2+}$ system hence statistical steric and electrostatic factors lead to lower stability constants of ternary system than the binary system of $\mathrm{Hm}$ in solution.

Table 1. Overall stability constants $(\log K)^{a}$ of binary $(1: 1)$ and ternary $(1: 1: 1)$ metal-ligand complexes formed in aqueous solution at $\mathrm{T}=25 \pm 0.1^{\circ} \mathrm{C}$ and $\mu=0.1 \mathrm{M} \mathrm{NaNO}_{3}$

\begin{tabular}{|c|c|c|c|c|c|c|c|c|}
\hline \multirow[t]{2}{*}{$\begin{array}{l}\text { Metal } \\
\text { Ions }\end{array}$} & \multicolumn{2}{|c|}{$\begin{array}{l}\text { M:5FU } \\
\log K_{M A}^{M}\end{array}$} & \multicolumn{2}{|c|}{$\begin{array}{l}\mathrm{M}: \mathrm{Hm} \\
\log K_{M L}^{M}\end{array}$} & \multicolumn{2}{|c|}{$\begin{array}{c}\text { M:5FU:Hm } \\
\log K_{M A L}^{M A}\end{array}$} & \multicolumn{2}{|c|}{$\Delta \log K$} \\
\hline & (a) & (b) & (a) & (b) & (a) & (b) & (a) & (b) \\
\hline Co(II) & $5.08 \pm 0.15$ & 5.91 & $6.21 \pm 0.15$ & 8.37 & $5.31 \pm 0.03$ & 5.25 & -0.90 & -3.12 \\
\hline $\mathrm{Ni}(\mathrm{II})$ & $5.91 \pm 0.06$ & 5.32 & $7.38 \pm 0.09$ & 8.86 & $5.99 \pm 0.06$ & 5.44 & -1.39 & -3.42 \\
\hline $\mathrm{Cu}(\mathrm{II})$ & $8.12 \pm 0.07$ & 8.22 & $9.74 \pm 0.14$ & 10.24 & $8.28 \pm 0.07$ & 7.88 & -1.46 & -2.36 \\
\hline $\mathrm{Zn}(\mathrm{II})$ & $6.11 \pm 0.15$ & 8.01 & $6.43 \pm 0.17$ & 8.32 & $6.32 \pm 0.14$ & 6.23 & -0.11 & -2.09 \\
\hline $\mathrm{Cd}(\mathrm{II})$ & $5.76 \pm 0.09$ & 6.02 & $6.02 \pm 0.13$ & 7.90 & $5.93 \pm 0.09$ & 5.85 & -0.09 & -2.05 \\
\hline
\end{tabular}

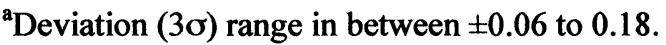

Method (a) Interpolation of Half $n$ values; (b) Average value method

$\Delta \operatorname{logK}$ : Difference between the stability constant of ternary complex and binary complex of secondary ligand.

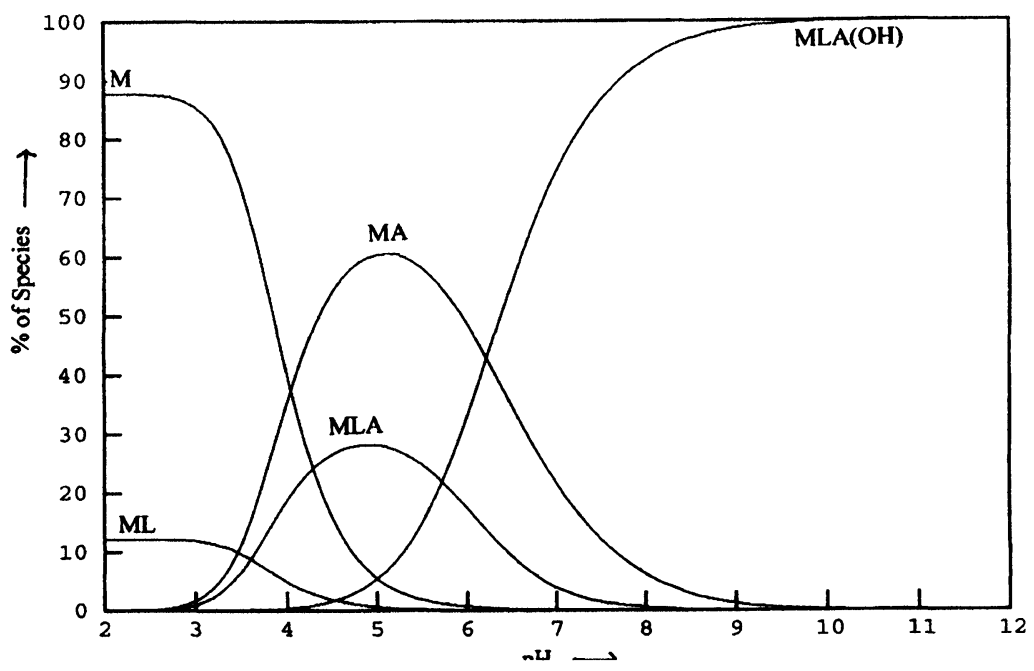

Fig. 3. Species distribution curve of Zn(II):5-fluorouracil:histamine (1:1:1) ternary system.

The species distribution for various possible species in solution has been performed for all the metal ions reported in the present work and the species distribution plot for $\mathrm{Zn}(\mathrm{II})-5 \mathrm{FU}-\mathrm{Hm}$ has been given in Fig. 3 as representative graph. Fig. 3 indicates the presence of free metal and 1:1 neutral complex of M-5FU in solution around $\mathrm{pH}$ 2.0. Their concentration start decreases with increase of the concentration of neutral species of $\mathrm{M}-\mathrm{Hm}$ and $\mathrm{M}-5 \mathrm{FU}-\mathrm{Hm}$ and attain almost a zero value at higher $\mathrm{pH}$ range. From the species distribution curve it can be stated further that the hydroxo species of ternary complex predominate the neutral species (i.e. $100 \%$ at $\mathrm{pH} 10.0$ ) being formed comparatively in small amounts in the lower $\mathrm{pH}$ range under investigation. Again formation of (1:1) neutral species suggests the bidentate nature of both the ligand in binary system. Same pattern of species distribution occurs in the ternary system of other metal ions. At $\mathrm{pH}$ 2.0 , free metals are present in $73 \%$ to $91 \%$ amount. Association of $5 \mathrm{FU}$ with each metal ions start at very low $\mathrm{pH}$ range $(\sim 2.0)$ resulting in the formation of $\mathrm{M}-5 \mathrm{FU}$ species in which metal ions distributed as: $\sim 12 \%$ for $\mathrm{Co}(\mathrm{II}), \mathrm{Cu}(\mathrm{II})$ and $\mathrm{Zn}(\mathrm{II}) ; \sim 8.5 \%$ in $\mathrm{Cd}(\mathrm{II})$ and $\sim 24 \%$ in $\mathrm{Ni}(\mathrm{II})$. 
Table 2. Analytical data of the complexes

\begin{tabular}{|c|c|c|c|c|c|c|}
\hline \multicolumn{7}{|c|}{ Amount Found (Calc.) (\%) } \\
\hline Complex & Color & M & $\mathrm{C}$ & $\mathrm{H}$ & $\mathrm{N}$ & $\begin{array}{l}\text { Melting } \\
\text { Point } \\
\left({ }^{\circ} \mathrm{C}\right) \\
\end{array}$ \\
\hline $\mathrm{Co}(5 \mathrm{FU})(\mathrm{Hm})(\mathrm{OH}) \cdot 2 \mathrm{H}_{2} \mathrm{O}$ & Light Pink & $\begin{array}{c}16.55 \\
(16.69)\end{array}$ & $\begin{array}{c}30.91 \\
(30.61)\end{array}$ & $\begin{array}{c}03.69 \\
(03.42)\end{array}$ & $\begin{array}{c}20.05 \\
(19.80)\end{array}$ & $>300$ \\
\hline $\mathrm{Ni}(5 \mathrm{FU})(\mathrm{Hm})(\mathrm{OH}) \cdot 2 \mathrm{H}_{2} \mathrm{O}$ & Green & $\begin{array}{c}16.54 \\
(16.64)\end{array}$ & $\begin{array}{c}30.04 \\
(30.63)\end{array}$ & $\begin{array}{c}03.36 \\
(03.43)\end{array}$ & $\begin{array}{c}19.37 \\
(19.84)\end{array}$ & 290 \\
\hline $\mathrm{Cu}(5 \mathrm{FU})(\mathrm{Hm})(\mathrm{OH}) \cdot 2 \mathrm{H}_{2} \mathrm{O}$ & Intense Green & $\begin{array}{c}17.63 \\
(17.76)\end{array}$ & $\begin{array}{c}30.47 \\
(30.22)\end{array}$ & $\begin{array}{c}03.48 \\
(03.38)\end{array}$ & $\begin{array}{c}19.67 \\
(19.58)\end{array}$ & 180 \\
\hline $\mathrm{Zn}(5 \mathrm{FU})(\mathrm{Hm})(\mathrm{OH}) \cdot 2 \mathrm{H}_{2} \mathrm{O}$ & White & $\begin{array}{c}18.05 \\
(18.18)\end{array}$ & $\begin{array}{c}30.48 \\
(30.06)\end{array}$ & $\begin{array}{c}03.42 \\
(03.36)\end{array}$ & $\begin{array}{c}19.55 \\
(19.48)\end{array}$ & $>300$ \\
\hline $\mathrm{Cd}(5 \mathrm{FU})(\mathrm{Hm})(\mathrm{OH}) \cdot 2 \mathrm{H}_{2} \mathrm{O}$ & White & $\begin{array}{c}28.81 \\
(27.65)\end{array}$ & $\begin{array}{c}27.76 \\
(26.59)\end{array}$ & $\begin{array}{c}03.03 \\
(02.97)\end{array}$ & $\begin{array}{c}17.42 \\
(17.22)\end{array}$ & $>300$ \\
\hline
\end{tabular}

Furthermore association of $\mathrm{Hm}$ with each metal ions and $\mathrm{M}-5 \mathrm{FU}$ start at $\mathrm{pH}$ range (i.e. $~ 3.0$ ) resulting in the formation of M-Hm and M-5FU-Hm species are as: 61\% - 72\% for $\mathrm{Cd}(\mathrm{II}), \mathrm{Co}$ (II) and $\mathrm{Zn}$ (II) at $\mathrm{pH} \sim 5.0$; $78 \%$ for $\mathrm{Cu}(\mathrm{II})$ at $\mathrm{pH} \sim 4.0 ; \sim 46 \%$ for $\mathrm{Ni}$ (II) at $\mathrm{pH} \sim 5.0$ and $\sim 11 \%-28 \%$ for $\mathrm{Cd}(\mathrm{II}), \mathrm{Co}$ (II) and $\mathrm{Zn}$ (II) at $\mathrm{pH} \sim 5.0 ; \sim 13 \%$ for $\mathrm{Cu}(\mathrm{II})$ at $\mathrm{pH} 3.0 ; \sim 38 \%$ for $\mathrm{Ni}(\mathrm{II})$ at $\mathrm{pH} 4.0$ respectively. Finally the total metal distributed into ML, MA and MLA species get converted into the hydroxo species (MLA(OH) $)$ at higher $\mathrm{pH}$ (i.e. > 8.0) and the metal ion distribution observed in about $100 \%$ at the corresponding $\mathrm{pH}$. Again species distribution data clearly show that the ternary complexes are less stable than binary complexes of secondary ligand.

All the isolated mixed ligand complexes are colored except those of $\mathrm{Zn}(\mathrm{II})$ and $\mathrm{Cd}(\mathrm{II})$ and involve 1:1:1 metal to $5 \mathrm{FU}$ to $\mathrm{Hm}$ ratio (where $\mathrm{M}=\mathrm{Co}(\mathrm{II}), \mathrm{Ni}(\mathrm{II}), \mathrm{Cu}(\mathrm{II}), \mathrm{Zn}(\mathrm{II})$ or $\mathrm{Cd}(\mathrm{II})$ ). Most of the complexes do not melt up to $300^{\circ} \mathrm{C}$ as reported in Table 2 .

Infrared studies

The infrared spectrum of 5FU is reported in the literature [5a] and IR band assignments for histamine have been made by comparing its spectrum with various amino acids reported in the literature [11-13]. Table 3 records some important infrared data for the ligands and their mixed complexes. Histamine molecule is potentially a bidentate and forms complex with bivalent cations through the imidazole nitrogen and the amino nitrogen. The neutral imidazolyl group of $\mathrm{Hm}$ exists in tautomeric equilibrium between $\mathrm{N}_{1}$-protonated form and the $\mathrm{N}_{3}$-protonated one. Either one of the unprotonated imidazole nitrogens of these tautomers can participate in coordination to metal ions. Basically histamine molecule has three coordinating sites viz. $\mathrm{N}_{1}, \mathrm{~N}_{3}$ imidazole nitrogen and amino nitrogen. As reported in the literature [11-13], it is sterically impossible for a $\mathrm{Hm}$ molecule to make a chelate ring with metal ions through $\mathrm{N}_{1}$ atom and amino nitrogen. This means that when $\mathrm{Hm}$ molecule will coordinate through $\mathrm{N}_{1}$ imidazole atom, its amino group will exist in the free and $\mathrm{NH}_{3}{ }^{+}$state. The imidazole nitrogen of $\mathrm{Hm}$ can also form hydrogen bonds. Infrared spectra of the complexes (Table 3) show shift in $\mathrm{NH}_{3}{ }^{+}$bands of $\mathrm{Hm}\left(3110 \mathrm{~cm}^{-1}\right)$ either toward lower frequency side or toward higher frequency side on coordination. The shifting of $\mathrm{vN}-\mathrm{H}$ band as compared to that in free $\mathrm{Hm}\left(3310 \mathrm{~cm}^{-1}\right)$ suggest the coordination of $\mathrm{Hm}$ through the nitrogen of amino group. This is further supported by the shift in the $\mathrm{VC}_{7}-\mathrm{N}$ band appearing at $1036 \mathrm{~cm}^{-1}$ in free $\mathrm{Hm}$.

The band observed at $1570 \mathrm{~cm}^{-1}$ and $1252 \mathrm{~cm}^{-1}$ in the spectrum of $\mathrm{Hm}$ can be assigned to the imidazole ring vibration of $\mathrm{Hm}$ for $\mathrm{N}_{3}$ and amino nitrogen. On coordination the imidazole ring vibration shifts toward lower or higher frequency sides (Table 3), suggesting the coordination of $\mathrm{Hm}$ of the metal ions through its $\mathrm{N}_{3}$ atom and amino nitrogen [14]. The bands at $1598 \mathrm{~cm}^{-1}$ in the spectrum of free $\mathrm{Hm}$ is assigned to the ring vibration of the imidazolyl group due to the $\mathrm{N}_{1}$ atom. This band in all complexes remains almost unchanged. Thus it may be concluded that in all these mixed complexes the $\mathrm{Hm}$ behaves as bidentate ligand coordinating to the central ion through its $\mathrm{N}_{3}$ atom and amino nitrogen. There are several possible binding sites in $5 \mathrm{FU}$ viz. $\mathrm{C}_{2}=\mathrm{O}, \mathrm{C}_{4}=\mathrm{O}, \mathrm{N}_{1}-\mathrm{H}$ and $\mathrm{N}_{3}-\mathrm{H}$ groups. Table 3 shows significant change in the frequency of $v-\mathrm{H}$ band in the complexes indicating that $\mathrm{N}_{3}-\mathrm{H}$ group takes part in coordination with metal ions in complex formation. In all complexes, a medium to strong metal-nitrogen stretching band appears in the range $242-260 \mathrm{~cm}^{-1}[15,16]$, indicating six coordination number around these metal ions. All of the mixed complexes exhibit $v \mathrm{O}-\mathrm{H}$ (aquo) bands at $3500-3250 \mathrm{~cm}^{-1}$ suggesting the presence of water molecules in the complexes [17]. The presence of 
vM-O (aquo) band in lower region of infrared spectrum and absence of $\mathrm{HOH}$ bending bands due to lattice water in 1630-1600 $\mathrm{cm}^{-1}$ region favour the coordinated nature of water molecules in these complexes [18].

Table 3. Relevant infrared data for ligands and their mixed complexes $\left(\mathrm{Cm}^{-1}\right)$

\begin{tabular}{llllllll}
\hline Band Assignment & Histamine & $5 \mathrm{FU}$ & $\mathrm{Co}(\mathrm{II})$ & $\mathrm{Ni}(\mathrm{II})$ & $\mathrm{Cu}(\mathrm{II})$ & $\mathrm{Zn}(\mathrm{II})$ & $\mathrm{Cd}(\mathrm{II})$ \\
\hline$v \mathrm{O}-\mathrm{H}$ & & - & $3410 \mathrm{w}$ & $3415 \mathrm{w}$ & $3420 \mathrm{w}$ & $3338 \mathrm{w}$ & $3440 \mathrm{w}$ \\
$v \mathrm{~N}-\mathrm{H}$ & $3310 \mathrm{~m}$ & - & $3330 \mathrm{~m}$ & $3328 \mathrm{~m}$ & $3290 \mathrm{~m}$ & $3260 \mathrm{w}$ & $3338 \mathrm{w}$ \\
$v \mathrm{~N}-\mathrm{H}$ & - & $3160 \mathrm{~m}$ & $3142 \mathrm{w}$ & $3145 \mathrm{w}$ & $3180 \mathrm{w}$ & $3185 \mathrm{w}$ & $3140 \mathrm{w}$ \\
$v \mathrm{NH}_{3}^{+}$ & $3110 \mathrm{w}, \mathrm{b}$ & - & $3135 \mathrm{w}$ & $3130 \mathrm{w}$ & $3130 \mathrm{w}$ & $3137 \mathrm{~m}$ & $3130 \mathrm{w}$ \\
$v \mathrm{C}=\mathrm{C}$ in phase & $1596 \mathrm{~s}, \mathrm{~b}$ & - & $1605 \mathrm{~s}$ & $1595 \mathrm{~m}$ & $1592 \mathrm{~s}$ & $1598 \mathrm{~s}$ & $1590 \mathrm{~s}$ \\
$v \mathrm{C}=\mathrm{C}$ of imidazole & & & & & & & \\
$\begin{array}{l}\left.\mathrm{N}_{1}\right) \text { ring } \\
v \mathrm{C}=\mathrm{C} \text { of imidazole }\end{array}$ & $1570 \mathrm{~m}$ & - & $1555 \mathrm{~m}$ & $1546 \mathrm{~m}$ & $1555 \mathrm{w}$ & $1550 \mathrm{w}$ & $1540 \mathrm{~s}$ \\
$\begin{array}{l}\left.\mathrm{N}_{3}\right) \text { ring } \\
\delta \mathrm{N}_{3}-\mathrm{H}\end{array}$ & - & $1430 \mathrm{~s}$ & $1426 \mathrm{w}$ & $1436 \mathrm{~m}$ & $1436 \mathrm{~m}$ & $1422 \mathrm{w}$ & $1435 \mathrm{~s}$ \\
$\begin{array}{l}\mathrm{Ring} \text { breathing for } \\
\text { amino nitrogen }\end{array}$ & $1252 \mathrm{~s}$ & - & $1274 \mathrm{~m}$ & $1273 \mathrm{w}$ & $1275 \mathrm{~m}$ & $1266 \mathrm{~s}$ & $1270 \mathrm{~m}$ \\
$v \mathrm{C} \alpha-\mathrm{N}$ & & & & & & & \\
$v \mathrm{M}-\mathrm{O}($ aquo $)$ & $1036 \mathrm{~s}, \mathrm{~b}$ & - & $1054 \mathrm{~m}$ & $1024 \mathrm{~m}$ & $1018 \mathrm{~m}$ & $1020 \mathrm{w}$ & $1054 \mathrm{~s}$ \\
$v \mathrm{M}-\mathrm{N}$ & - & - & $408 \mathrm{~m}$ & $408 \mathrm{~m}$ & $474 \mathrm{~m}$ & $368 \mathrm{~m}$ & $355 \mathrm{~m}$ \\
\hline
\end{tabular}

\section{Electronic spectral and Magnetic studies}

The magnetic moments of $\mathrm{Cu}$ (II) complex (Table 4) shows the presence of one unpaired electron. The d-d transition bands appearing in the region $600-900 \mathrm{~nm}$ for $\mathrm{Cu}(\mathrm{II})$ complex, favours distorted octahedral geometry around $\mathrm{Cu}(\mathrm{II})$ ion in the complex [19]. As reported in the literature that $\mathrm{Co}$ (II) high spin octahedral complexes have magnetic moment ranging from 4.7 to 5.2 B.M. and tetrahedral complexes have magnetic moment range 4.4 to $4.8 \mathrm{~B}$.M. whereas $\mathrm{Ni}$ (II) octahedral complexes have magnetic moment 2.9 to $3.4 \mathrm{~B} . \mathrm{M}$. and tetrahedral complexes have magnetic moment 3.5 to 4.2 B.M. [20]. The $\mu_{\text {eff }}$ values and position of electronic spectral bands of present $\mathrm{Co}$ (II) and $\mathrm{Ni}(\mathrm{II})$ complexes as shown in Table 4 suggest octahedral geometry for $\mathrm{Co}(\mathrm{II})-5 \mathrm{FU}-\mathrm{Hm}$ and $\mathrm{Ni}(\mathrm{II})-5 \mathrm{FU}-\mathrm{Hm}$ complexes $[19,21]$.

Table4.Solid state (Nujol-Mull) electronicspectral and magnetic momentdata(305.5K) of metaloomplexes.

\begin{tabular}{lll}
\hline Complexes & $\lambda_{\max }(\mathrm{nm})$ & $\mu_{\text {eff }}$ (B.M.) \\
\hline $\mathrm{Co}(5 \mathrm{FU})(\mathrm{Hm})(\mathrm{OH}) .2 \mathrm{H}_{2} \mathrm{O}$ & 550,830 & 4.95 \\
$\mathrm{Ni}(5 \mathrm{FU})(\mathrm{Hm})(\mathrm{OH}) .2 \mathrm{H}_{2} \mathrm{O}$ & 395,670 & 3.21 \\
$\mathrm{Cu}(5 \mathrm{FU})(\mathrm{Hm})(\mathrm{OH}) .2 \mathrm{H}_{2} \mathrm{O}$ & 610 & 2.01 \\
\hline
\end{tabular}

$X$-ray diffraction studies

X-ray diffraction data (Table 5) of the complexes were indexed according to the method of Ito [22]. The indexing pattern yields the lattice constants $\mathrm{a}=7.32 \AA, \mathrm{b}=7.01 \AA$, and $\mathrm{c}=6.79 \AA$ for $\mathrm{Zn}$ (II) complex indicating orthorhombic symmetry for this complex.

On the basis of above spectroscopic studies, the octahedral structure has been proposed for all these complexes.

\section{Antitumour activity studies}

It has been observed that the ligand 5FU has significant antitumour activity with $\mathrm{T} / \mathrm{C}$ value 136 at $12.5,150$ at 25.0 and 154 at $50.0 \mathrm{mg} / \mathrm{kg}$ body weight against Dalton's lymphoma tumour system. Among the ternary complexes of histamine, $\mathrm{Co}(\mathrm{II})-5 \mathrm{FU}-\mathrm{Hm}$ and $\mathrm{Zn}(\mathrm{II})-5 \mathrm{FU}-\mathrm{Hm}$ have pronounced antitumour activity with T/C values more than 125 at all the reported doses (Table 6). All the experimental mice treated with $\mathrm{Zn}(\mathrm{II})-5 \mathrm{FU}-$ $\mathrm{Hm}$ complex survived beyond six month at the dose of $50.0 \mathrm{mg} / \mathrm{kg}$ body weight. The other compounds are not effective against Dalton's lymphoma tumour system at these doses. The Table 7 shows the result obtained 
were supplemented with $20 \mu \mathrm{g} / \mathrm{mL}$ gentamycin, $100 \mu \mathrm{g} / \mathrm{mL}$ streptomycin, $100 \mu \mathrm{g} / \mathrm{mL}$ penicillin and $10 \%$ heat-inactivated fetal calf serum (Biological Industries, Haemak, Israel). All test compounds were suspended in phosphate buffered saline solution (PBS) ( $\mathrm{pH} \mathrm{7.0)}$.

Table 6. Screening data of mixed ligand complexes for antitumour activity against Dalton's lymphoma in vivo

\begin{tabular}{lcccrc}
\hline Compounds & $\begin{array}{l}\text { Dosage ip } \\
\text { injection mg/kg } \\
\text { body weight }^{\mathrm{a}}\end{array}$ & $\begin{array}{l}\text { Mean Lifespan } \\
\text { of non survivors }_{\text {T/C (days) }}\end{array}$ & $\begin{array}{l}\text { No. of mice } \\
\text { Surviving } \\
>6 \text { months }\end{array}$ & T/C \% & \% ILS \\
\hline $5 \mathrm{FU}$ & 12.5 & $30 / 22$ & - & 136.36 & 36.36 \\
& 25.0 & $33 / 22$ & - & 150.00 & 50.00 \\
$\mathrm{Co}(5 \mathrm{FU})(\mathrm{Hm})(\mathrm{OH}) .2 \mathrm{H}_{2} \mathrm{O}$ & 50.0 & $34 / 22$ & - & 154.54 & 54.54 \\
& 12.5 & $38 / 22$ & - & 172.72 & 72.72 \\
& 25.0 & $35 / 22$ & - & 159.09 & 59.09 \\
$\mathrm{Ni}(5 \mathrm{FU})(\mathrm{Hm})(\mathrm{OH}) .2 \mathrm{H}_{2} \mathrm{O}$ & 50.0 & $36 / 22$ & - & 163.36 & 63.63 \\
& 12.5 & $25 / 22$ & - & 113.63 & 13.63 \\
& 25.0 & $20 / 22$ & - & 90.90 & - \\
$\mathrm{Cu}(5 \mathrm{FU})(\mathrm{Hm})(\mathrm{OH}) .2 \mathrm{H}_{2} \mathrm{O}$ & 50.0 & $24 / 22$ & - & 109.09 & 09.09 \\
& 12.5 & $16 / 22$ & - & 72.72 & - \\
& 25.0 & $08 / 22$ & - & 36.36 & - \\
$\mathrm{Zn}(5 \mathrm{FU})(\mathrm{Hm})(\mathrm{OH}) .2 \mathrm{H}_{2} \mathrm{O}$ & 50.0 & $13 / 22$ & - & 59.09 & - \\
& 12.5 & $35 / 22$ & - & 159.09 & 59.09 \\
& 25.0 & $33 / 22$ & - & 150.00 & 50.00 \\
$\mathrm{Cd}(5 \mathrm{FU})(\mathrm{Hm})(\mathrm{OH}) .2 \mathrm{H}_{2} \mathrm{O}$ & 50.0 & all alive & $6(100)$ & - & - \\
& 12.5 & $19 / 22$ & - & 86.36 & - \\
& 25.0 & $14 / 22$ & - & 63.63 & - \\
& 50.0 & $03 / 22$ & - & 13.63 & -
\end{tabular}

$\mathrm{T}=$ tumoured, $\mathrm{C}=$ control; $\mathrm{ILS}=$ increased lifespan

${ }^{a} \mathrm{~A}$ single ip injection of the reported dose was given to six mice in each experiment.

${ }^{\mathrm{b}}$ In calculating average survival time, mice surviving $>6$ months were not included.

Table 7. Screening data of mixed ligand complexes for antitumour activity against Sarcoma-180 in vivo

\begin{tabular}{|c|c|c|c|c|c|}
\hline Compounds & $\begin{array}{l}\text { Dosage ip } \\
\text { injection } \mathrm{mg} / \mathrm{kg} \\
\text { body weight }^{\mathrm{a}}\end{array}$ & $\begin{array}{l}\text { Mean Lifespan } \\
\text { of non survivors } \\
T / C \text { (days) }\end{array}$ & $\begin{array}{l}\text { No. of mice } \\
\text { Surviving } \\
>6 \text { months }\end{array}$ & $\begin{array}{l}\mathrm{T} / \mathrm{C} \\
\%\end{array}$ & \% ILS \\
\hline \multirow[t]{3}{*}{$5 \mathrm{FU}$} & 12.5 & $13 / 7$ & - & 185.7 & 85.7 \\
\hline & 25.0 & $11 / 7$ & - & 157.1 & 57.1 \\
\hline & 50.0 & all alive & $6(100)$ & - & \\
\hline \multirow[t]{3}{*}{$\mathrm{Co}(5 \mathrm{FU})(\mathrm{Hm})(\mathrm{OH}) \cdot 2 \mathrm{H}_{2} \mathrm{O}$} & 12.5 & $10 / 7$ & - & 142.8 & 42.8 \\
\hline & 25.0 & $12 / 7$ & - & 171.4 & 71.4 \\
\hline & 50.0 & $18 / 7$ & - & 257.1 & 157.1 \\
\hline \multirow[t]{4}{*}{$\mathrm{Ni}(5 \mathrm{FU})(\mathrm{Hm})(\mathrm{OH}) \cdot 2 \mathrm{H}_{2} \mathrm{O}$} & 12.5 & $08 / 7$ & - & 114.2 & 14.2 \\
\hline & 25.0 & $06 / 7$ & - & 85.7 & - \\
\hline & 50.0 & $05 / 7$ & - & 71.4 & - \\
\hline & 12.5 & $07 / 7$ & - & 100.0 & - \\
\hline \multirow[t]{3}{*}{$\mathrm{Cu}(5 \mathrm{FU})(\mathrm{Hm})(\mathrm{OH}) \cdot 2 \mathrm{H}_{2} \mathrm{O}$} & 25.0 & $08 / 7$ & - & 114.2 & 14.2 \\
\hline & 50.0 & $06 / 7$ & - & 85.7 & - \\
\hline & 12.5 & $17 / 7$ & - & 242.8 & 142.8 \\
\hline \multirow[t]{3}{*}{$\mathrm{Zn}(5 \mathrm{FU})(\mathrm{Hm})(\mathrm{OH}) \cdot 2 \mathrm{H}_{2} \mathrm{O}$} & 25.0 & $10 / 7$ & - & 142.8 & 42.8 \\
\hline & 50.0 & $13 / 7$ & - & 185.7 & 85.7 \\
\hline & 12.5 & $04 / 7$ & - & 57.1 & - \\
\hline \multirow[t]{2}{*}{$\mathrm{Cd}(5 \mathrm{FU})(\mathrm{Hm})(\mathrm{OH}) \cdot 2 \mathrm{H}_{2} \mathrm{O}$} & 25.0 & $03 / 7$ & - & 42.8 & - \\
\hline & 50.0 & $02 / 7$ & - & 28.5 & - \\
\hline
\end{tabular}

$\mathrm{T}=$ tumoured, $\mathrm{C}=$ control; ILS = increased lifespan

${ }^{a}$ A single ip injection of the reported dose was given to six mice in each experiment.

${ }^{b}$ In calculating average survival time, mice surviving $>6$ months were not included. 
Table 8. Percentage inhibition of ${ }^{3} \mathrm{H}$-Thymidine incorporation in Dalton's lymphoma, Sarcoma-180 and L-929 Tumor Cell in vitro*

\begin{tabular}{lccc}
\hline Compound & \multicolumn{3}{c}{ Dose } \\
& $5 \mu \mathrm{g} / \mathrm{ml}$ & $10 \mu \mathrm{g} / \mathrm{ml}$ & $20 \mu \mathrm{g} / \mathrm{ml}$ \\
\hline $\mathrm{Co}(5 \mathrm{FU})(\mathrm{Hm})(\mathrm{OH}) .2 \mathrm{H}_{2} \mathrm{O}$ & 50.36 & 48.04 & 29.02 \\
$\mathrm{Zn}(5 \mathrm{FU})(\mathrm{Hm})(\mathrm{OH}) .2 \mathrm{H}_{2} \mathrm{O}$ & 92.15 & 93.24 & 95.28 \\
& & & \\
$5 \mathrm{FU}$ & 47.36 & $\mathbf{S - 1 8 0}$ & 57.80 \\
$\mathrm{Co}(5 \mathrm{FU})(\mathrm{Hm})(\mathrm{OH}) .2 \mathrm{H}_{2} \mathrm{O}$ & 23.75 & 50.08 & 92.29 \\
$\mathrm{Zn}(5 \mathrm{FU})(\mathrm{Hm})(\mathrm{OH}) .2 \mathrm{H}_{2} \mathrm{O}$ & 36.32 & 54.79 & 85.85 \\
& & & \\
$5 \mathrm{FU}$ & - & $\mathbf{L - 9 2 9}$ & 49.93 \\
$\mathrm{Co}(5 \mathrm{FU})(\mathrm{Hm})(\mathrm{OH}) .2 \mathrm{H}_{2} \mathrm{O}$ & - & 64.73 & 65.53 \\
$\mathrm{Zn}(5 \mathrm{FU})(\mathrm{Hm})(\mathrm{OH}) .2 \mathrm{H}_{2} \mathrm{O}$ & - & 30.27 & 32.15 \\
\hline
\end{tabular}

*This table shows the results obtained for the compounds which show significant inhibition.

\section{Potentiometric pH Titration}

Solutions of $\mathrm{Co}(\mathrm{II}), \mathrm{Ni}(\mathrm{II}), \mathrm{Cu}(\mathrm{II}), \mathrm{Zn}(\mathrm{II})$ and $\mathrm{Cd}(\mathrm{II})$ nitrates were prepared in double distilled water and standardized by EDTA titration method [23]. Ligand solutions of $0.01 \mathrm{M} 5 \mathrm{FU}$ and $0.01 \mathrm{M} \mathrm{Hm}$ were also prepared in double distilled water. Stocks solutions of sodium nitrate $(1.0 \mathrm{M})$ and standard nitric acid $(0.02$ M) were used. Carbonate-free $\mathrm{NaOH}(0.2 \mathrm{M})$ solution was standardized against oxalic acid solution and used as titrant.

All the measurements were carried out at $25 \pm 0.1^{\circ} \mathrm{C}$ using Schott CG841 pH-meter. The six mixtures A, B, $\mathrm{C}, \mathrm{D}, \mathrm{E}$ and $\mathrm{F}$ were prepared and titrated separately against $0.2 \mathrm{M} \mathrm{NaOH}\left(\mathrm{CO}_{2}\right.$-free) bubbling $\mathrm{N}_{2}$ in the cell during the titration: (A) $\mathrm{HNO}_{3}(0.02 \mathrm{M}, 5.0 \mathrm{ml})+\mathrm{NaNO}_{3}(1.0 \mathrm{M}, 5.0 \mathrm{ml})+$ water; (B) $\mathrm{HNO}_{3}(0.02 \mathrm{M}, 5.0$ $\mathrm{ml})+\mathrm{NaNO}_{3}(1.0 \mathrm{M}, 5.0 \mathrm{ml})+5 \mathrm{FU}(0.01 \mathrm{M}, 5.0 \mathrm{ml})+$ water; (C) $\mathrm{HNO}_{3}(0.02 \mathrm{M}, 5.0 \mathrm{ml})+\mathrm{NaNO}_{3}(1.0 \mathrm{M}$, $5.0 \mathrm{ml})+5 \mathrm{FU}(0.01 \mathrm{M}, 5.0 \mathrm{ml})+$ metal solution $(0.01 \mathrm{M}, 5.0 \mathrm{ml})+$ water; (D) $\mathrm{HNO}_{3}(0.02 \mathrm{M}, 10.0 \mathrm{ml})+$ $\mathrm{NaNO}_{3}(1.0 \mathrm{M}, 5.0 \mathrm{ml})+\mathrm{Hm}(0.01 \mathrm{M}, 5.0 \mathrm{ml})+$ water; (E) $\mathrm{HNO}_{3}(0.02 \mathrm{M}, 10.0 \mathrm{ml})+\mathrm{NaNO}_{3}(1.0 \mathrm{M}, 5.0$ $\mathrm{ml})+\mathrm{Hm}(0.01 \mathrm{M}, 5.0 \mathrm{ml})+$ metal solution $(0.01 \mathrm{M}, 5.0 \mathrm{ml})+$ water; $(\mathrm{F}) \mathrm{HNO}_{3}(0.02 \mathrm{M}, 10.0 \mathrm{ml})+\mathrm{NaNO}_{3}$ $(1.0 \mathrm{M}, 5.0 \mathrm{ml})+5 \mathrm{FU}(0.01 \mathrm{M}, 5.0 \mathrm{ml})+$ metal solution $(0.01 \mathrm{M}, 5.0 \mathrm{ml})+\mathrm{Hm}(0.01 \mathrm{M}, 5.0 \mathrm{ml})+$ water. In each case, the total volume was maintained at $50.0 \mathrm{ml}$ and ionic strength $0.1 \mathrm{M}\left(\mathrm{NaNO}_{3}\right)$.

\section{Preparation of the complexes}

Solution of $(1 \mathrm{~m}$ mole) metal nitrates in $15 \mathrm{ml}$ ethanol and $5 \mathrm{FU}(1 \mathrm{~m}$ mole) in $30 \mathrm{ml}$ ethanol were obtained by heating. Both the warm solutions were mixed and the volume of the resultant mixture was reduced to about $50 \%$ by heating with constant stirring. The precipitates were obtained at $\sim \mathrm{pH} 8$ by adding aqueous sodium hydroxide solution. Keeping the precipitates in an ice bath and on adding an aqueous solution of $(1 \mathrm{~m}$ mole) histamine to it, a clear solution was obtained. The solid complexes were obtained by concentrating the above solution at $\sim 60{ }^{\circ} \mathrm{C}$ to $5 \mathrm{ml}$ and on adding diethyl ether. The precipitate was filtered washed with absolute ethanol several times, finally with anhydrous diethyl ether and dried at $\sim 50^{\circ} \mathrm{C}$.

The analysis of $\mathrm{C}, \mathrm{H}$ and $\mathrm{N}$ were carried on Perkin-Elmer model $240 \mathrm{C}$ elemental analyzer. The metal ions were determined by dissolving the complexes in dilute nitric acid and titrating against EDTA [23]. The infrared spectra of the complexes were registered on a Perkin-Elmer 783 spectrophotometer. The electronic spectra of complexes were registered in the solid state with a Perkin-Elmer Lambda $35 \mathrm{UV} / \mathrm{VIS}$ spectrophotometer in the range of 200-1100 nm. Magnetic susceptibility measurements at $305.5 \mathrm{~K}$ were done by Faraday magnetic susceptibility balance and X-ray powder data were obtained on Philips PW 1710 diffractometer using $\mathrm{Cu}-\mathrm{K} \alpha$ radiation.

\section{Antitumor activity evaluation}


The antitumour activity both in vivo and in vitro of the mixed ligand complexes has been evaluated according to the method reported elsewhere [24]. The antitumour response was also measured as median survival time (days) in which median life span was determined and the percentage of increased life span (ILS) was calculated as

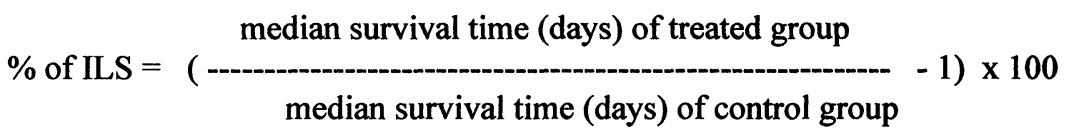

According to the National Cancer Institute [25], the criterion for a significant therapeutic effect is $\geq 30 \%$ ILS for P388 leukemia (ip).

ACKNOWLEDGMENTS

Authors are grateful to UGC, New Delhi for the financial assistance.

\section{REFERENCES}

1. Hiedelberger, C.; Chaudhuri, N. K.; Danneberg, P.; Mooren, D.; Grelsbach, L.; Duschinsky, R.; Schnitzer, R. J.; Pleven, E.; Scheiner, J. Nature, 179, 663, 1957.

2. Fox, J. J.; Wempen, I. J. Med. Chem., 9, 101, 1966.

3. Rosenberg, B.; Van Camp, L. Cancer Res., 30, 1799, 1970.

4. Joshi, K. C. J. Indian Chem. Soc., 63, 187, 1986.

5. (a) Singh, U. P.; Ghose, R.; Ghose, A. K. Inorg. Chim. Acta, 136, 21, 1987. (b) Singh, U. P.; Ghose, R.; Ghose, A. K. Indian J. Cancer Chemotherapy, 10, 147, 1988; 13, 33, 1991. (c) Singh, U. P.; Ghose, R.; Ghose, A. K.; Sodhi, A.; Singh, S. M.; Singh, R. K. J. Inorg. Biochem., 37, 325, 1989.

6. Singh, S.; Ghose, A. K. J. Indian Chem. Soc., 73, 650, 1996.

7. (a) Fernandes, M.; Maria, C.; Paniago, E. B.; Carvalho, S. J. Braz. Chem. Soc., 8, 537, 1997. (b) Torok, I.; Tamas, G.; Bela, G.; Toth, G. K.; Peter, A. J. Chem. Soc., Dalton Trans., 1205, 1998. (c) Drozdzewski, P.; Kordon, E. Spectrochim. Acta, Part A, 56, 1299, 2000. (d) Szabo-Planka, T.; Rockenbauer, A.; Korecz, L; Nagy, D. Polyhedron, 19, 1123, 2000.

8. (a) Bjerrum, J. Metal Ammine Complex Formation in Aqueous Solution, Haase, Copenhagen, 1941. (b) Irving, H. M.; Rossotti, H. S. J. Chem. Soc., 3397, 1953; 2904, 1954. (c) Chidambaram M. V.; Bhattacharya, P. K. J. Inorg. Nucl. Chem., 32, 3271, 1970.

9. Motekaitis, R. J.; Martell, A. E. Determination and Use of Stability Constants, VCH Publishers, New York, 1989.

10. Lee, J. D. Concise Inorganic Chemistry, 4th Edn., Chapman and Hall Ltd, London, 1991.

11. Larson, L., Acta Chem. Scand., 4, 27, 1950.

12. Itabashi, M.; Shoji, K.; Itoh, K. Inorg. Chem., 21, 3484, 1982.

13. Boudreav, P. A.; Hopper, R. J. J. Inorg. Nucl. Chem., 39, 1247, 1977.

14. Eilbeck, W. J.; Holmes, F.; Phillips, G. G.; Underhill, A. E. J. Am. Chem. Soc., 89, 1161, 1967.

15. Ghose, R. Inorg. Chim. Acta, 156, 303, 1989.

16. Goodgame, M.; Johns, K. W. J. Chem. Soc. Dalton, 1294, 1978.

17. Speca, A. N.; Mikulski, C. M.; Iaconianni, F. J.; Pytteuski L. L.; Karayannis, N. M. Inorg. Chim. Acta, 37, L551, 1979.

18. Nakamoto, K. Infrared spectra of Inorganic and Coordination Compounds, 2nd edition, Wiley Interscience, New York, 1970.

19. Lever, A. B. P. Inorganic Electronic Spectroscopy, Elsevier, Amsterdam, 1968.

20. Cotton F. A.; Wilkinson, G. Advanced Inorganic Chemistry, 5th edition, Wiley Interscience, New York, 1988.

21. Martin, J. W. L.; Timmons, J. H.; Martell, A. E.; Willis, C. J. Inorg. Chem., 19, 2328, 1980.

22. Azaroff, L. V. Elements of X-ray Crystallography, New York, 1964.

23. Flaschka, H. A. EDTA Titration, Pergamon, 1964.

24. Singh, U. P.; Ghose, R.; Ghose, A. K.; Singh, R. K.; Sodhi, A.; Geeta, B. Indian J. Cancer Chemother., 13, 45, 1991.

25. Geran, R. E.; Greenberg, N. H.; MacDonald, M. M.; Schumaker, A. M.; Abbott, B. J. Cancer Chemother. Rep., 3, 1, 1972. 